\title{
Pelapisan Aktivitas Lipase Dari Bakteri Sedimen Perairan Pulau Lemukutan
}

\author{
Kristina Adelita $^{1 *}$, Nora Idiawati ${ }^{1}$, Mega Sari Juane Sofiana ${ }^{1}$ \\ 1 Program Studi Ilmu Kelautan, FMIPA, Universitas Tanjunpura, Pontianak- \\ Indonesia \\ *Correspondence email: Kristina Adelita \\ $\triangle$ kristinaadelita123@gmail.com
}

\author{
Received:17 December 2018- Accepted: 02 January 2019 \\ Published: 28 February 2019 @ Author(s) 2019. This article is open access
}

\begin{abstract}
Enzim merupakan katalisator yang mengkatalis proses biokimia yang terjadi didalam maupun diluar. Enzim bekerja secara spesifik terhadap substrat tertentu, salah satunya adalah lipase. Lipase dapat menghidrolisis lipid atau lemak menjadi asam lemak dan gliserol. Tujuan dari penelitian ini adalah untuk mengetahui aktivitas lipase pada bakteri sedimen laut dari Perairan Pulau Lemukutan. Isolasi bakteri dari bakteri sedimen laut diperoleh sebanyak 4 isolat. Penapisan aktivitas enzim ekstraseluler dilakukan untuk mengetahui potensi isolat bakteri sedimen laut dalam menghasilkan enzim lipase. Uji aktivitas lipase dengan metode agar yang diperkaya dengan tween 80. Hasil uji aktivitas ezim lipase menunjukan tidak adanya aktivitas enzim lipase pada semua isolat bakteri sedimen laut.
\end{abstract}

Keywords: Lipase, bakteri sedimen laut, Lemukutan

\section{Pendahuluan}

Secara administratif Pulau Lemukutan merupakan wilayah Kecamatan Sungai Raya Kepulauan, Kabupaten Bengkayang Provinsi Kalimantan Barat (Sudiono, 2008). Pulau lemukutan memiliki potensi besar yang dapat meningkatkan kesejahteraan dan perekonomian bagi masyarakat. Penduduk Pulau Lemukutan Mayoritas berprofesi sebagai nelayan, berkebun cengkeh, budidaya rumput laut dan jasa angkut kapal motor (Sudarso, 2012).

Enzim merupakan molekul protein yang sangat spesifik yang tersusun oleh sel dari unit-unit sederhana asam amino. Enzim mengikat molekul substrat sehingga membentuk enzim substrat yang bersifat sementara (Lehninger, 1995). Enzim merupakan katalisator yang mengkatalis proses biokimia yang terjadi didalam maupun diluar sel (Poedjiadi, 1994). Enzim bekerja secara spesifik terhadap substrat tertentu, salah satunya adalah lipase.

Lipase merupakan enzim yang memisahkan ikatan ester pada lemak sehingga terbentuk asam lemak dan gliserol (Poedjiadi, 1994). Manfaat enzim lipase sangat luas digunakan dalam berbagai bidang seperti industri tekstil, parmasi, makanan, detergen, dan kertas (Ullah et al., 2016). Enzim yang berasal dari laut tahan terhadap lingkungan yang ekstrim seperti salinitas dan suhu yang tinggi serta kondisi alkali (Akbari et al., 2016). Enzim tidak hanya ditemukan pada makanan, minuman, maupun tumbuhan tetapi juga dapat ditemukan pada lingkungan laut. Penelitian mengenai enzim lipase pada lingkugnan laut telah banyak dilakukan. Bakteri laut Pseudomonas putida SBS037 dari muara 


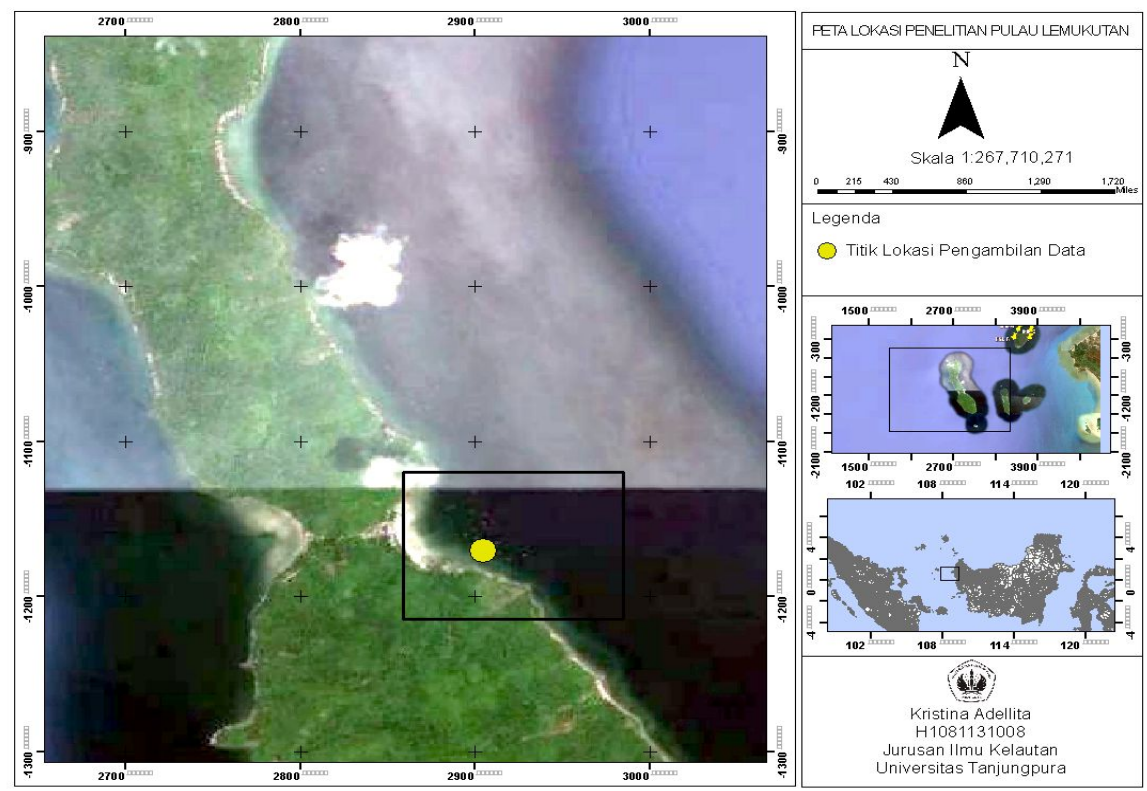

Gambar 1. Lokasi pengambilan sampel

vellar berpotensi menghasilkan enzim lipase (Sivasubramani et al., 2013). Planomicrobium okeanokoites ABN-IAUF-2 dari Teluk Persia berpotensi menghasilkan enzim lipase (Akbari et al., 2016). Engyodontium sp. berpotensi menghasilkan enzim lipase (Lanka and Trinkle, 2017).

\section{Metode}

\subsection{Waktu dan tempat}

Penelitian ini dilaksanakan pada bulan Mei 2017 hingga Agustus 2018. Pengambilan sampel dilakukan di Perairan Pulau Lemukutan, Kabupaten Bengkayang, Kalimantan Barat seperti yang terlihat pada Gambar 2. Isolasi bakteri dan pengujian aktivitas antibakteri dilakukan di Laboratorium Bioteknologi Riset dan Laboratorium Mikrobiologi, FMIPA Universitas Tanjungpura.

\subsection{Alat dan Bahan}

Alat-alat yang digunakan pada saat pengambilan sampel sedimen adalah SCUBA botol falcon, cool box, dan plastik steril. Alat yang digunakan di laboratorium yaitu autoklaf, inkubator, laminar air flow, lemari pendingin, shaker, neraca analitik, hotplate, vortex, mikroskop, mikropipet, cawan petri, tabung reaksi, tabung durham, Erlenmeyer, gelas ukur, gelas beker, kaca objek, jarum ose, spatula, pipet tetes, termometer, jangka sorong, dan bunsen.

Bahan-bahan yang digunakan dalam penelitian ini adalah sampel sedimen, air laut, akuades, etanol 70\%, pepton, yeast extract, natrium klorida, glukosa, laktosa, maltosa, manitol, tween 80, kristal violet, larutan iodin, larutan safranin, larutan peroksida, oxidase disk, bromtimol biru, parafin, phenol red, simmon's sitrat, urea base agar.

\subsection{Prosedur Pengambilan Sampel}

Pengambilan sampel sedimen menggunakan SCUBA. Sampel sedimen diambil $130 \mathrm{~m}$ dari pantai pada kedalaman $5 \mathrm{~m}$. Sampel sedimen diambil dengan menggunakan botol falcon steril. Sampel dimasukkan ke dalam cool box untuk selanjutnya di isolasi di laboratorium.

\section{4 Analisis Data \\ 2.4.1 Isolasi dan Morfologi Bakteri Sedimen Laut}

Sampel sedimen ditimbang sebanyak $1 \mathrm{~g}$. Sampel kemudian di suspensi dalam air laut steril $45 \mathrm{~mL}$ dan diencerkan hingga 10-4. Sampel bakteri hasil pengenceran 10-2 10-4 diambil masing-masing $100 \mu \mathrm{l}$ dan ditumbuhkan pada media agar dengan metode tuang dan di inkubasi selama 5 hari pada suhu $37^{\circ}$ Morfologi koloni bakteri yang terbentuk diamati diameter, warna, bentuk, elevasi, serta tepian koloni.

\subsubsection{Uji Aktivitas Enzim Amilase Bakteri Sedimen Laut}

Aktivitas enzim lipase diuji berdasarkan Bairagi et al. (2000). Isolat yang diperoleh dari hasil isolasi diinokulasikan ke cawan 


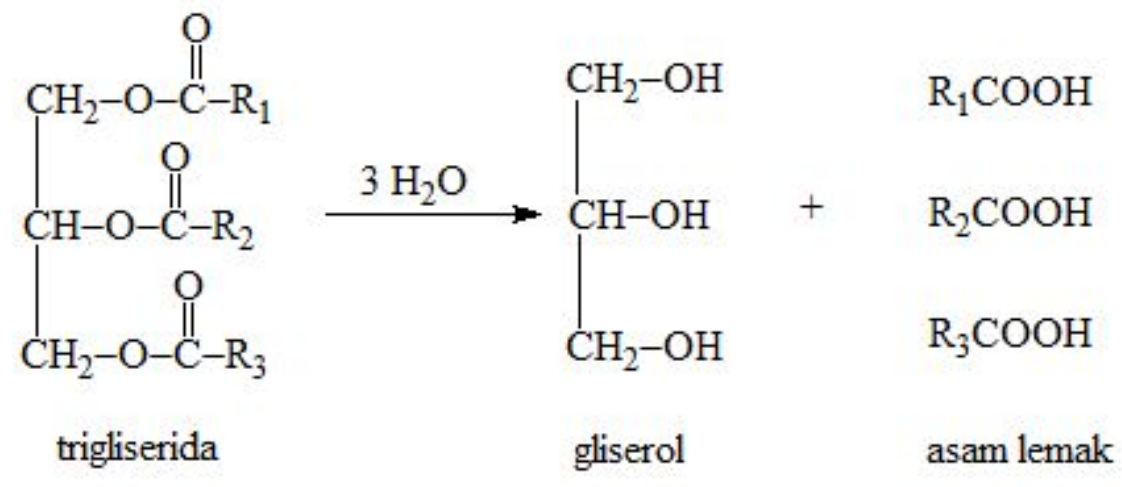

Gambar 3. Ikatan ester pada trigliserida, gliserol dan asam lemak

Tabel 1. Morfologi Koloni Isolat Bakteri Sedimen

\begin{tabular}{llllll}
\hline Kode Bakteri & Diameter $(\mathbf{m m})$ & Warna & Bentuk & Elevasi & Tepian \\
\hline SKA01 & 0,48 & Putih & bulat & datar & bergelombang \\
SKA02 & 0,69 & Putih & bulat & cembung & bergelombang \\
SKA03 & 1,42 & Putih & bulat & datar & bergerigi \\
SKA04 & 0,41 & Putih & bulat & datar & bergerigi \\
\hline
\end{tabular}

Tabel 2. Hasil Seleksi Heterofik Berdasarkan Kemampuan Lipase Bakteri Sedimen Laut

\begin{tabular}{lc}
\hline \multirow{2}{*}{ Isolat } & Isolat Bakteri \\
\cline { 2 - 2 } SKA01 & Lipase \\
& \\
SKA02 & - \\
\end{tabular}

petri yang berisi media NA yang diperkaya Tween 80. Isolat bakteri sedimen ditumbuhkan dengan menggoreskannya ditengah petri dan di inkubasi selama 24 jam pada suhu $37^{\circ}$. Aktivitas enzim lipase ditandai dengan terbentuknya endapan asam lemak berwarna putih keruh disekitar petri.

\section{Hasil dan Pembahasan}

Pengambilan sampel sedimen dilakukan pada tanggal 7 Mei 2017 di Perairan Pulau Lemukutan (Gambar 2). Hasil isolasi dari bakteri sedimen di peroleh sebanyak 4 isolat. Berdasarkan hasil pengamatan morfologinya diperoleh koloni dengan perbedaan diameter, warna, bentuk, tepian, dan elevasi (Tabel 1). Hasil isolasi yang diperoleh selanjutnya dilakukan uji aktivitas enzim lipase guna

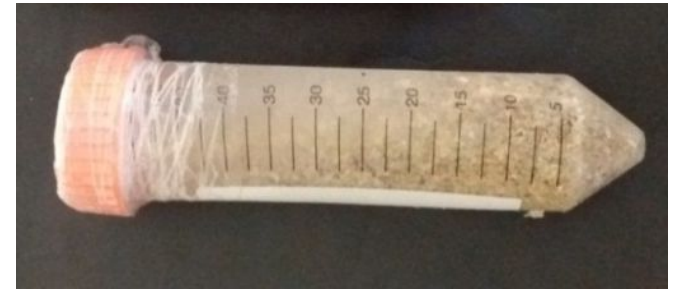

Gambar 2. Sampel sedimen laut

melihat pontensi enzim lipase pada isolat bakteri sedimen.

Isolat bakteri sedimen laut selanjutnya diuji aktivitas enzimnya untuk mengetahui aktivitas enzimatis isolat bakteri sedimen laut dengan uji lipase. Hasil uji lipase pada semua isolat bakteri sedimen laut diperoleh hasil negatif karena tidak menunjukan adanya aktivitas enzim lipase. Hal tersebut 
terjadi karen enzim yang terdapat pada media tidak dapat mengubah lipid menjadi rantai pendek dan asam lemak yang digunakan untuk pertumbuhan bakteri (Tabel 3). Jika positif mengandung enzim lipase maka enzim akan memisahkan ikatan ester pada lemak sehingga terbentuk asam lemak dan gliserol (Gambar 3).

\section{Kesimpulan}

Berdasarkan penelitian yang telah dilakukan mengenai penapisan aktivitas antibakteri sedimen laut dapat disimpulkan bahwa berdasarkan hasil uji lipase pada isolat bakteri sedimen laut tidak menunjukan adanya aktivitas enzim lipase.

\section{Ucapan Terima Kasih}

Penulis mengucapkan ucapan terima kasih kepada Pemerintah Daerah Kabupaten Sekadau dan Community Development \& Outreaching Universitas Tanjungpura yang telah memberikan beasiswa penuh Satu Dusun Satu Sarjana (SDSS) sehingga penulis dapat menyelesaikan studi di FMIPA Untan.

\section{Daftar Pustaka}

Akbari E., K. Beheshti-Maal, and H. Nayeri. 2016. Production and Optimization of Alkaline Lipase by a Novel Psychrotolerant and Halotolerant Strain Planomicrobium okeanokoites ABN-IAUF-2 Isolatedfrom Persian Gulf. J. Medical Research and Health Sciences. :139-148

Bairagi A.K., Ghosh S., Kumarsen, and A.K. Ray. 2002. Enzyme Producing Bacterial Flora Isolated from Fish Ddigestive Ttracts. $J$. Aquaculture International. 10:109-121

Lanka S. and T.B. Trinkle. 2017. Screening and Isolation of Lipase Producing Fungi from Marine Water Obtained from Machilipatnam Costal Region. J. IPPR. 7:928-932.

Lehninger A.L. 1982. Dasar-dasar Biokimia, Thebawidjaja M. (alih bahasa). Jakarta: Erlangga.

Poedjiadi A. 1994. Dasar-dasar Biokimia. Jakarta: Universitas Indonesia (UI-Press).

Sivasubramani K., J.R. Singh, S. Jayalakshmi, S.S. Kumar, and C. Selvi. 2013. Production and Optimization of Lipase from Marine Derived Bacteria, J. ICMAS. 4-126-135.

Sudarso J. 2012. Strategi Pengembangan Ekowisata Terumbu Karang di Pulau Lemukutan dan Pulau randaian, Kabupaten Bengkayang, Kalimantan Barat. Tesis. Jakarta: UT.

Sudiono, G. 2008. Analisis Pengelolaan Terumbu Karang Pada Kawasan Konservasi Laut Daerah (KKLD) Pulau Randayan dan
Sekitarnya Kabupaten Bengkayang Provinsi Kalimantan Barat. Tesis. Semarang: UNDIP.

Ulluh S., I. Malook, K.U. Bashar, M. Riaz, M.M. Aslam, Z.U. Rehman, M. Fayyaz, and M. Jamil. 2016. Purification and Application of Lipases from Pseudomonas Species. $J$. Biosciences. 2:111-116. 